\title{
PROJECT FINANCE AS SUPPORT TO AGRICULTURAL PRODUCTION
}

\author{
Maxim A. Ivanov \\ Kursk State Agricultural Academy named after I.I. Ivanov, K. Marx St., 70, Kursk, Russian Federation
}

\begin{abstract}
:
There is a need to use new financial instruments in agroindustrial production, since the existing mechanisms of crediting and subsidizing of interest rates are not sufficiently effective. The agriculture is characterized by low profitability which does not allow producers to use effectively borrowed funds as their cost grows at advancing rates. As a result of using the bank credits, the financial situation in agricultural enterprises has deteriorated, triggering the need for development of new financial instruments that would enable agricultural producers to access funding sources more easily. Accordingly, the paper proposes the use of project financing mechanisms. Also, the authors recommend improving the methods of project assessment with the aim of providing the most effective financial support to agroindustrial production. The implementation of the proposed method will allow for improving the mechanisms of support to agricultural producers.
\end{abstract}

\section{INTRODUCTION}

During the period of sanctions, Russia needs to increase the volume of agricultural production. Specific resource groups are to be used in order to achieve agricultural production increase. Those groups are the following: financial, land and labor group. In our view, the issue of financing of creation and to a lesser extent the expansion of agricultural production is the most difficult. This is due to the specifics of agricultural production and difficulty of using the data for the purposes of own resources of manufacturers due to a relatively high debt load of the agricultural sector.

With regard to sanctions, it is necessary to revise and update the priorities of macroeconomic policy tools, primarily monetary. In recent years, the Bank of Russia practically drove all monetary policy to a lower level of inflation. To this end, the bulk of oil and gas revenues "was frozen" in the accounts of the Central Bank; significantly reduced refinancing of banks; increasing the standard of emergency (Ayvazov, 2013).

As a result of this policy, there was underfunding investment in infrastructure, high technology, real sectors of the economy. The continuation of this policy calls into question the possibility of transition to innovation and investment development path of the Russian economy in general and in particular, agricultural economy.

In order to coordinate fiscal and monetary policy of the Central Bank and the Government of the Russian Federation, they should not be placed before mutually exclusive goals. Therefore, in our view, the primary objective of monetary policy in Russia is to look for the ways to increase the budget and bank financing for investment in socio-economic and technological development without a sharp increase in inflation. For this purpose, it is advisable to consider a significant reduction of refinancing rate, so that the banks are able to lend to the real sector of the economy; increase investment spending budget; exempt from compulsory redundancy term deposits of citizens in order to be insured against double burdens; reduce the cost of banks in order to reduce bank margins, considering the payment of interest on commercial banks' mandatory reserve in the fund, and correspondent accounts with the Central Bank of Russia.

All of these measures will enhance the ability of bank lending and investment budget, which will lead to a further increase in the volume of gross domestic product, increased demand for cash resources, revitalize the real economy and thus contribute to return of the majority of government spending in the budget in taxes (Maslov, 2009).

The main problem of Russian agrarian economy is drawback of finances which were provided by the State program and the empowerment of medium - and long - term lending. Along with the tools enabling discretionary monetary policy, it is necessary to provide the use of discretionary fiscal policy measures in a stimulating way (increasing subsidies and grants).

The effectiveness of any kind of economic policy is determined by the ratio of the results (effects) to the cost of its implementation. The greatest effect can be reached only by combining the tools of fiscal and monetary policy. If we compare the effectiveness of fiscal and monetary policy, then, from our point of view, in terms of decline in production and the effects of the fiscal policy instruments, the decline will be higher than the monetary policy effects, especially if you can reduce the sensitivity of investment to interest rate changes. We should actively use the financial leverage due to their high mobility. 
In this regard, we consider it appropriate to take into account the possibility of applying such a mechanism of investment resources as project financing. The method is not traditional for the Russian banking system, but we suppose that it will be quite perspective. Financing is defined as "providing the necessary financial resources of the entire economy of the country, regions, businesses, entrepreneurs and citizens, as well as the various economic programs and economic activities" (Raizberg, Lozovskiy \& Starodubtseva, 2006).

Accordingly, project financing in the broadest sense can be defined as "a method of attracting long-term debt financing for large projects through the" financial engineering " (Raizberg, Lozovskiy \& Starodubtseva, 2006), based on the loan under the cash flow generated only by the project; it depends on the creation of a detailed assessment of the project, operational risks and the risks of income and their distribution among investors, creditors and other stakeholders on the basis of contracts and other contractual arrangements" (Yeskomb, 2008). In this regard, project finance is a global process that involves many participants and all aspects of project development and implementation, the contractual relationship into a single system. Such financing is usually aimed at implementation of major projects, often followed by a large public importance: related to the extraction of natural resources, financing of independent power projects, public infrastructure (roads, transport, public buildings), etc.

The narrow understanding of project financing with direct participation of credit institutions is the placement of attracted funds for implementation of certain projects. Unlike conventional loan, in which the source of repayment of borrowed funds is the whole economic activity of the client, with project financing source of repayment of credit debt is the cash inflow resulting from the implementation of a specific project.

The legal basis for this type of funding is still the same loan agreement concluded, usually in the form of a credit line. This form of cooperation is most convenient for the bank, as it allows to keep records of target use of funds by the borrower, the borrower's financial condition, as well as compliance with the stages of the project. These loan agreements often provide the opportunity for the bank to charge an interest rate unilaterally, or a list of grounds for denial of the current tranche of the loan, for the purpose of demanding early repayment of the loan amount together with interest. For example, a bank may provide in the loan agreement the right to increase the interest rate in case of delay in repayment by the borrower of this loan or absence of a stipulated term documentary evidence of registration with the relevant authorities of the Federal Registration Service of Russia for state registration of mortgage (mortgage) facility under construction, the pledgee for which the bank acts (Alekseeva, 2008).

In the case of the need to finance large-scale projects really, banks tend to unite their efforts in order to issue a syndicated loan to the borrower. This is due not so much to desire of banks to minimize their credit, foreign exchange, interest and legal risks, but the need to comply with the reserve policy of the Bank of Russia.

In accordance with the provisions of the Bank of Russia № 254-P, the credit institution is obliged to classify loans issued in one of five categories of quality (to the extent of that collateral for granted loans), and create reserves for portfolios of homogeneous loans to the amount of principal (which are not included: due to law, business practice or the provi- sion of loan payments in the form of interest for the use of the loan, fees, penalties and other payments in favor of the credit institution resulting from the agreement on the loan) (The position of the Central Bank № 254-P “Order of formation of credit organizations of reserves for possible loan losses Loan and similar debts", 2004).

The requirements of the Bank of Russia were pretty tough. Thus, to include a loan from the second to fifth category of quality, the bank is required to obtain certain software. The provision of loan implies providing a collateral, bank guarantees, the guarantee deposit (deposit), divided into one of two categories of quality software, installed above Regulations № 254-P. For example, to ensure I category of quality it may include: a pledge of listed securities of countries having an investment grade rating not lower than "BBB" according to classification rating agency S\&P (Standard \& Poor's) or the rating not lower than the classifications "Fitch Ratings", "Moody's" as well as securities of the central banks of these countries or the Bank of Russia bonds, securities issued by the Ministry of Finance, etc.

Typically, banks make out collateral relating to the II category of quality: liquid collateral objects listed in the Regulation № 254-P, guarantees (bank guarantees), guarantees, etc. The higher the loan amount, the more significant will be supplied to the loan that fell within at least the third category of quality in which case banks are obliged to create reserves in the amount of 21 to $50 \%$ based on the amount of principal. Speaking of lower quality categories $\left(4^{\text {th }}\right.$ and $\left.5^{\text {th }}\right)$, the bank must create reserves to $100 \%$ of the principal amount.

Project financing provides the customer with a number of advantages: the possibility of expanding existing businesses, attracting additional funds, separation of financial flows on current and project business, attracting long-term financial resources, individual approach on the part of the bank, the possibility of phased investment of own funds in the project and using collateral assets acquired during the project, as well as comprehensive banking services (including consulting in the preparation of business projects).

This type of funding also features purpose - the creation or implementation of major projects, the funds for which it is difficult to accumulate a narrow circle of participants.

Funds in project financing may be directed to:

- The purchase of non-residential real estate in the secondary market or the real estate objects of unfinished construction;

- Purchase of land for an investment project;

- Construction work on new construction, as well as reconstruction, restoration or capital construction;

- The acquisition of fixed assets for modernization and reconstruction of production;

- The creation of new production capacity, etc.

This type of lending is relevant for use in metallurgy, electric power, food, wood and petroleum industries.

The main criteria for making an investment decision about the use of public funding in the implementation of regional investment projects are indicators of economic efficiency of the project (part of the total for all years of the regional investment project produced gross regional product in the region of the Russian Federation, which can be provided as a result of the implementation of this investment project) and indicators of financial performance of the project (net present value and internal rate of return of the project) (Order of the Ministry of Regional Development of 
the Russian Federation № 117 “On approval of the Methodology of calculating and applying the criteria of efficiency of regional investment projects", 2008)

In this regard, we consider relevant to build a model that allows to carry out an initial evaluation of the feasibility of project financing based on the indicators of financial leverage. The model is based on the following assumptions:

1. Tax corrector is assumed to be 0.94 in all cases. Speaking of enterprises, the agricultural tax payer of the single tax rate is 6 per cent for companies applying the common system of taxation, income tax rate of 0 per cent, so the assumption used in the model will provide some slack performance differential gearing.

2. The level of the average interest rate on the loan is taken as $17 \%$, taking into account possible fluctuations in the financial market in terms of sanctions. The average settlement rate on loans to businesses in 2014 amounted to $15 \%$ (The average rate on loans to legal entities in 2014, The average rate on loans to individuals in 2014 , 2015).

3. The minimum rate of return on assets is assumed to be $16 \%$, as at smaller index value of financial leverage effect will be negative, therefore, the project can not be accepted for implementation.

4. The maximum value of the lever arm may not exceed 5 , as in this case, the borrower will not be able to provide effective security for repayment of borrowings.

5. Fees due to the specifics of agricultural production are carried out once a year.

6. Project payback period is rounded to the nearest whole number.

Table 1. The main indicators for making decision on the project financing

\begin{tabular}{lrrrrr}
\hline Name & \multicolumn{5}{c}{ Indicator value } \\
\hline The lever arm & 1 & 2 & 3 & 4 & 5 \\
\hline $\begin{array}{l}\text { The differential lever } \\
\begin{array}{l}\text { The level of financial } \\
\text { leverage effect }\end{array}\end{array}$ & 1 & 1 & 1 & 1 & 1 \\
\hline
\end{tabular}

Without discounting the cash income, the maximum payback period for which the project can be recommended for adoption at a given level of profitability is 7 years. The present value of cash flow of the project will be -IC (invested capital) ++ CF (cash flow) / 2,826.

\section{SUMMARY}

Despite the fact that project finance is now a very popular lending tool, its practical application is not very developed due to the incompleteness and conflicts of law. In particular, the legal framework of project finance in various sectors of the market should be adjusted: the granting of concessions and guarantees, insurance, syndicated right, the stock market, trust, leasing operations, and others. At the same time, this mechanism potentially allows, through the creation of new agricultural producers, implementation of import substitution programs, and facilitates the creation of new jobs in the agricultural sector.

\section{REFERENCES}

Alekseeva D.G. (2008). Commercial and Project Finance. Laws of Russia, Issue 10.

Ayvazov, A. (2013). Fiscal rule is the hand brake of the Russian economy. Retrieved November 1, 2015 from http://www. regnum.ru/news/1654009.html.

Credit-professional. (2014). The average rate on loans to legal entities in 2014. Retrieved November 1, 2015 from http:// credit-professional.ru/protsentnyie-stavki/srednyaya-stavka-po-kreditam-dlya-yuridicheskih-lits-v-2014-godu.html

Garant. (2004). The position of the Central Bank on March 26, 2004 № 254-P "Order of formation of credit organizations of reserves for possible loan losses Loan and similar debts". Retrieved November 1, 2015 from http://base.garant.ru/584458/

Invest-profit. (2015). The average rate on loans to individuals in 2014. Retrieved November 1, 2015 from http://www.investprofit.ru/banki/kreditovanie/1597-stavki-po-kreditam-yuridicheskim-licam.html

Maslov, V.V. (2009). Reproduction and financial relations in the agrarian sector of the economy (the theory, methodology, practice). Retrieved November 1, 2015 from http://dibase. ru/article/12052009_maslovavv/1

Raizberg, B.A. Lozovskiy, L.S., \& Starodubtseva, E.B. (2006). Modern Dictionary of Economics. Moscow: INFRA-M LTD.

Raizberg, B.A., Lozovskiy, L.S., \& Starodubtseva E.B. (2008). Order of the Ministry of Regional Development of the Russian Federation of July 31, 2008 № 117 “On approval of the Methodology of calculating and applying the criteria of efficiency of regional investment projects". Retrieved November 1, 2015 from http://base.consultant.ru/cons/CGI/online. cgi?req=doc;base $=$ LAW;n=79095

Yeskomb, E.R. (2008). The principles of project financing / Printsipy proektnogo finansirovaniya. Moscow, Sent-Petersbourg: Wershina publishing house.

\section{PROJEKTNO FINANSIRANJE KAO VID PODRŠKE AGROINDUSTRIJSKOJ PROIZVODNJI}

\section{Apstrakt:}

Sve više je prisutna potreba za korišćenjem novih instrumenata finansiranja u agroindustrijskoj proizvodnji s obzirom da postojeći mehanizmi kreditiranja i subvencionisanja kamatnih stopa nisu dovoljno produktivni. Agroindustriju odlikuje niska stopa zarade koja ne dozvoljava proizvođačima da adekvatno koriste pozajmljena sredstva, a njihove kamatne stope beleže sve veći rast u poslednje vreme. Kao rezultat korišćenja bankarskih kredita, finansijsko stanje takvih preduzeća se pogoršava, te stoga proizilazi i potreba za razvojem novih i lakše dostupnih finansijskih instrumenata za poljoprivredne proizvođače. U tom smislu predlažemo korišćenje mehanizma projektnog finansiranja. U radu se takođe ističe neophodnost unapređivanja tehnika procene projekata u cilju postizanja što efikasnije finansijske podrške agroindustrijskoj proizvodnji. Primena navedenih metoda doprineće poboljšanju mehanizama za pružanje finansijske podrške poljoprivrednim proizvođačima.

\section{Ključne reči:}

supstitucija uvoza, državna pomoć,

krediti,

agroindustrijska proizvodnja. 